\section{EET and CAR}
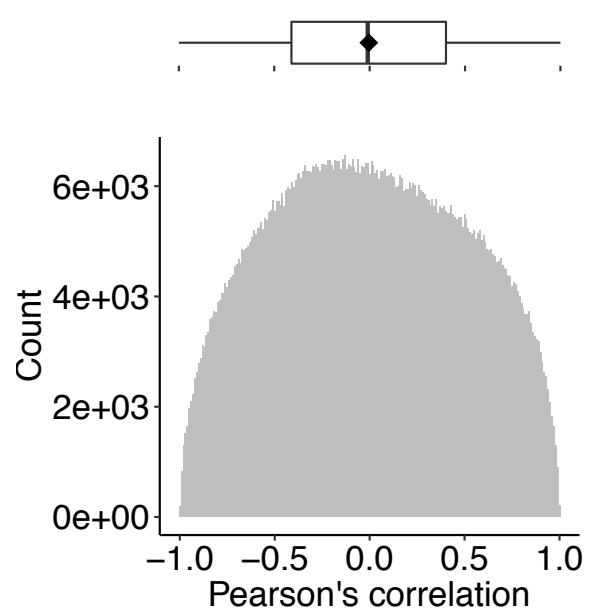

\section{EET and CAR}
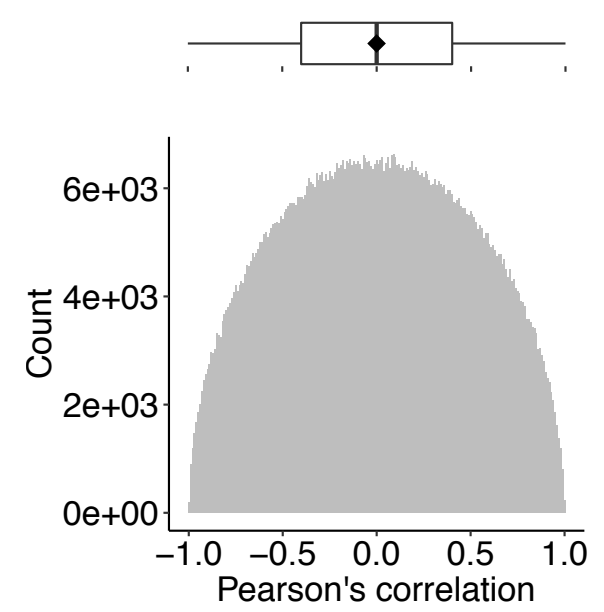